\title{
Neuronal network information processing through heterogeneities and resonance frequency shifts
}

\author{
Elizabeth Shtrahman ${ }^{1 *}$, Michal Zochowski ${ }^{2}$ \\ From Twenty Second Annual Computational Neuroscience Meeting: CNS*2013 \\ Paris, France. 13-18 July 2013
}

How can groups of neurons selectively encode different memories? We investigated a possible mechanism for the selective activation of regions of a network based on the resonance properties of individual neurons and heterogeneities in the network connectivity. In network simulations of coupled resonate and fire neurons, we incorporated the experimentally observed phenomena of resonance frequency shift based on membrane voltage changes. We aim to understand to what extent the resonance frequency shift allows for the separation of signals. We find that formation of neuronal subgroups, whether through higher connectivity strength or number of connections can lead to different activation properties from the rest of the network.

\section{Acknowledgements}

This work was supported by NSF CMMI 1029388 (MZ), NSF PoLS 1058034

(MZ).

\section{Author details}

'Department of Physics, University of Michigan, Ann Arbor, Ml 48109, USA. ${ }^{2}$ Department of Physics, University of Michigan, Ann Arbor, Ml 48109, USA.

Published: 8 July 2013

doi:10.1186/1471-2202-14-S1-P361

Cite this article as: Shtrahman and Zochowski: Neuronal network

information processing through heterogeneities and resonance

frequency shifts. BMC Neuroscience 2013 14(Suppl 1):P361.

* Correspondence: Ishtrah@umich.edu

'Department of Physics, University of Michigan, Ann Arbor, MI 48109, USA

Full list of author information is available at the end of the article
Submit your next manuscript to BioMed Central and take full advantage of:

- Convenient online submission

- Thorough peer review

- No space constraints or color figure charges

- Immediate publication on acceptance

- Inclusion in PubMed, CAS, Scopus and Google Scholar

- Research which is freely available for redistribution

Submit your manuscript at www.biomedcentral.com/submit
() Biomed Central
C Biomed Central

(c) 2013 Shtrahman and Zochowski; licensee BioMed Central Ltd. This is an Open Access article distributed under the terms of the Creative Commons Attribution License (http://creativecommons.org/licenses/by/2.0), which permits unrestricted use, distribution, and reproduction in any medium, provided the original work is properly cited. 